\title{
人體歐氏管筋, 組織學的研究
}

\author{
Dr. Kaname Okada : Uber den histologischen \\ Bau von Tubenmuskeln des Menschen.
}

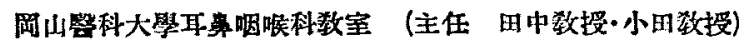

學士 岡 男要

\section{內容自次}

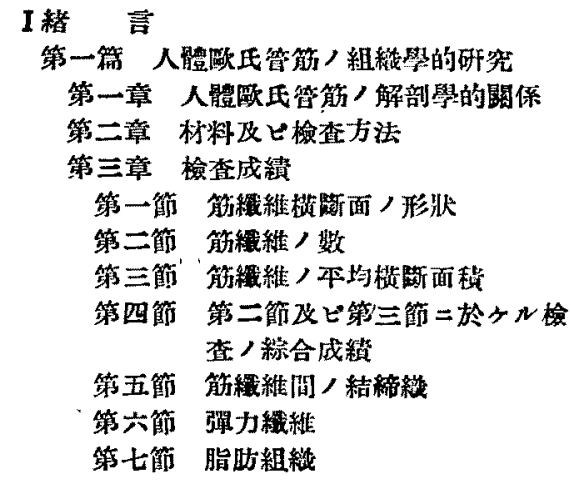

緒

聽器卜上氣道卜，間二何等カ，連絡ノフル 事八. 既二古クョリ想像サレタル所ナルガ. 菑際二歐氏管，存在 $习$ 解剖學的二記载七ル八 Eustachio ニシテ.之16 世紀ノ牛，事ナリ。 爾來歐氏管，機丵二關シテへ. 幾多先人，興味 アソソル所ナリ。1684 年 Schellhammer 八久

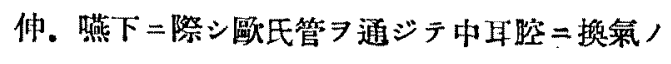
起ル事ヨ報告シ.1704 年 Valsalva 八歐氏管二 因ル中耳腔，換氣八、口蓋張笳ノ働キ二因ルモ ノナリト發表七リ。更 $=1853$ 年 Toynbee 八

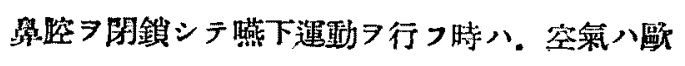
氏管:ア介シテ中耳院二流入シテ耳内二歷迫感

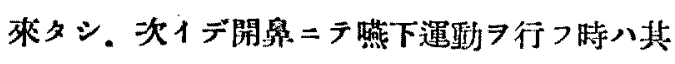
陉迫感八除刃ル。之八歐氏管が静止時二八閉鎖

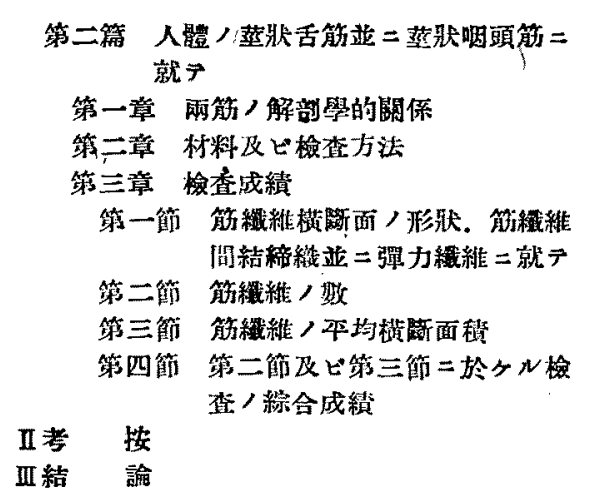

\section{툴}

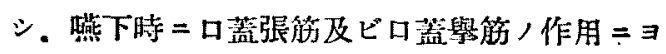
リ開通スルタメナリトセり。次イデ 1863 年

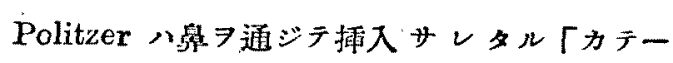
テル」=接續七ル「マ,メーター」=ョッテ.

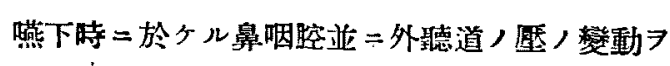
研究之．融氏管，生理＝奇與スル所大ナルモ， フリタリ。次イデ 1864 年 Trö.tsch 八歐氏管

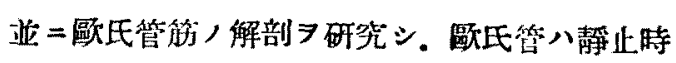
ニ八其粘膜壁八互二密着シ閏鎖，狀態ニアリ.

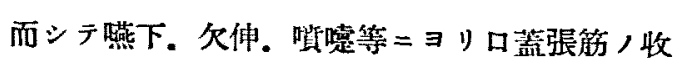
縮习東タ七儿場合二一過性=歐氏管腔，閉大ガ 行ハル、モノナリト七リ。其後融氏管ノ機能= 就イテ八多数ノ先人，研究澲續=接スル所ナル

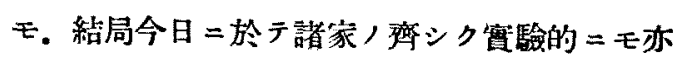


臨林的二モ承認スル所八，歐氏管八靜止時二八 其管腔八閉鎖シテ居リ．呬下，久伸，深呼吸。 强キ發畐時等/如ク生理的二歐氏管紡，收縮 7 來タス場合 =開通シ．中耳腔，換氣，行ハル、 モノト考へラル。

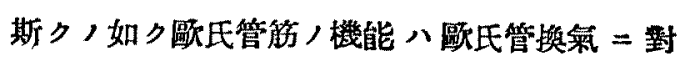
シ.甚ダ重要ナル役割ア有スル事ハ明カーシテ. 之ガ梂能障碍八必然的二其換氣障碍郎千歐氏管 狹管ナル現象 7 惹起スル事八亦想像 = 難カラ ズ. 而シテ卧二モ述べシ如ク從來歐氏管，生理 並二解剖=關シテ八. 之迄多數，先人，研究莱
䋶习見. 現今倘ホ且ツ論議サ几、所ナルガ。一方

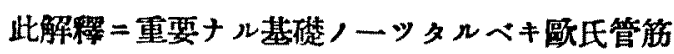
，組織舉的研究》。余，調查七几籍園=於テ八 未ダ之ョ見ズ.

依ツテ余 八玄 $=$ 歐氏管筋ノ組織學的檢索

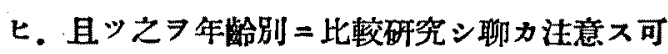
キ結果 7 得タり。佾木更二之二影照スル二，蒸

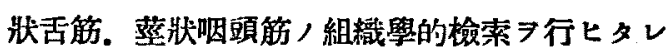
バ. 次二歐氏管筋並二之等諸筋 =就 1 テ記載七 ントス.

\section{第一篇 人體歐氏管筋ノ組織學的研究

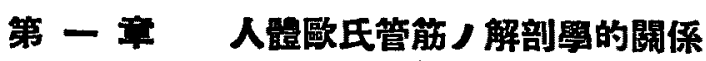

人體歐氏管筋トシテハ. 1) 口点張筇。2) 口

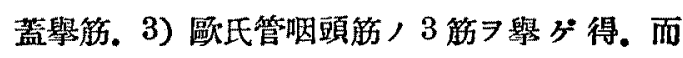
シテ歐氏管咽頭筋ハ小且ッ不定ニシテ. 主要筋 トシテ八前二者郎チ口篮張筋及ビ 口蓋舉筋ナ y.

1) 口蓋張筋(M. tensor veli palatini) 本筋八楔狀骨，舟狀窝ヨリ起り。其起始部， 前方八垔狀突起根部. 後方八鿇棘 (Spina anguralis）=及ビ. 更二一部，緎維八歐氏管，膜 樣部ヨリモ始マル。本筇八其起始部二於テ最モ

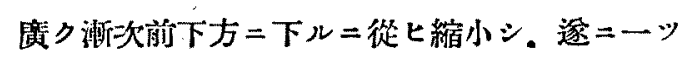
ノ腱トナッテ翼銁(Hamulus pterygoideus)= 附着シ。其形狀八略 $ミ 三$ 角形 薄板 シテえョり更 $=$ 翼銁ヨ圍繞シ内方 $=$ 届シ，再ビ

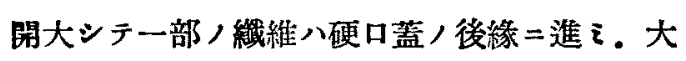
部分，穖維八正中線二於テ他側，夫レト連交 x。

而シテ本筋ノ作用二就イテハ. Tröltsch 八歐 氏管 7 解剖學的 $=$ 檢索シ. 歐氏管ハ一側八軟骨
ヨコ。他㑡八運動可能ナル薄板ヨリナル事 摘シ。靜止時ニハ之等兩者ノ粘膜相接シテ歐氏 管八闒鎖スルモノナリ。而シテ口篮張筋ハ楔狀 骨及ビ歐氏管骨部ョリ起始スルガ. 又一部，㵶 維八歐氏管膜柡部 $ョ$ モ始マル 以テ 本筋， 收縮が起儿場合(例一バ蔡下運動ノ場合)歐氏管 㷬棫板ノ粘膜八. 歌氏管㳄骨部ノ粘膜ヨリ遊離 シ。歐氏管ハ開大スルモノナリト七リ。Politzer 八動物/尼娟，頭蓋內二於テ. 本筋 7 支配 ルト考へラル、三叉神經 7 電浄的 $=$ 刺战シ。其 際軟口蓋，運動現象卜同時=歐氏管，撗大 タセリト發表シ. Rüdinger 八程々ナル動物ノ 歐氏管 7 此較研究七ル際。本筋 7 歐氏管愅大筋 (M. dilatator tubae) ト名付ヶタリ。即チ本筋 八今日 $=$ 於亏歐氏管㜔大 $=$ 最モ重要ナル役割 有スルモノト考へラル。

2) 口蓋譽笳(M. levator veli palatini) 本筋八前者, 後內側 = 位置シ. 起始部八側頭骨 ，錐體下面. 外頸動胍口ノ前部及ビ歌氏管軟骨 
等ニシテ． 又其緎維ノ一部八歐氏管下總トモ密 青ス。而シテ本筋八㰧氏管下壁二平行シ扁平圆 塼狀，矮形 頭口ニ於テーツ/粘膜隆廵 (Levator wulst) 7 造ル。之ョリ更二閉大シテロ篮二移行シ．正中 線ア越へテ他側ノ夫レト交錯ス。

本筋,作用八Troltsch =ヨレバ. 口蓝張筋二 對スル拮抗筋ナリトス。郎手本筋が收槯ス儿場 合八重厚トナリ．必然的二歌氏管膜樣部八内方 一涯七ラレ。其軟骨部卜膜椂部ト八互=密着シ。 因ッテ歐氏管ハ狭小トナルト說ケリ. Tourtual モ亦本筋ガ收縮スル場合。本筋/長軸八短縮シ 歐氏管八脄小トナルト言ヒ. Politzer 八本管， 收縮，際歐氏管底及ビ歐氏管咽頭口ガ譽上サル ルトシ. Semeleder 八人體ノ鼻鏡检查二於テ 本䈤，收維／際二八㰧氏管咽頭口ノ狹小トナル ヨ見ルト言へリ。然レドモBryant，歐氏管，

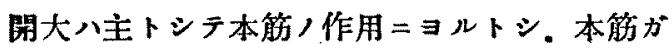
收縮スル際。歐氏管底习舉上シ，依ツテ管腔八
略に三角形习透り閉大スト說キ.Worms, Coulouma 及 Varseveld 八本筋/働キ二因ッテ歐

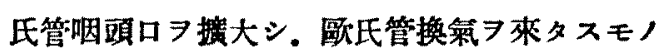
ナリト言ヘリ.

又 Rebsmann 八口蓋張筋，口蓋擧筋/兩者相 協カシテ，初メテ歌氏管ハ窗大スト言ヒ，安藤 モ办. 家鬼及ビ海猽二於テ兩筋，機能廢紦，實 驗ニョリテ：㙨能的歐氏管不通 シテ 兩箈八歐氏管ニ對シテ何レモ擴大筋ナリ ト馀ケリ。

以上述ベシ所ヨリシテ 本筋 筋ナリトナスニ八。現今份ホ異論アル所ナリ。

3）歐氏管咽頭筋(M. salpingopharyngeus) 本筋八咽頭口蓋筋 (M. pharyngopalatinus) ノ一部 シナシ.歐氏管軟骨下秎前端ヨリ起始シ。 後下方 =走り咽頭媵壁=附着ス。其作用八咽頭 及ビ啹頭フ舉上スルト同時二，歐氏管咽頭端 率引シ以テ歐氏管開口部=開大的二働クモノト 考へラル。

\section{第二革材料及ビ检查方法}

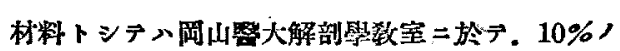

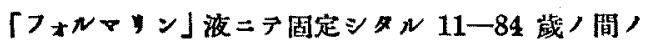

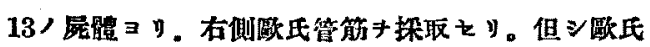
管咽㽬筋八小且ツ不定ナレバ之キ除外シ。主トシテ

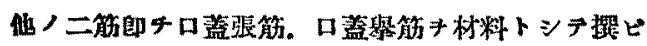
\$. ע.

探取をル雨筇ハ更二10\%「フォルマリン」液ニア 1

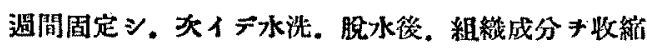
セシムル事坫キ閣「メチルアルコール・チェロイず ン」法ニョり包埋をり。而シテ其包埋をル筋肉入第

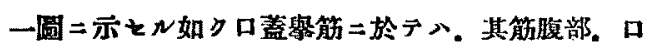
蓋張筋二於テハ三角形キナセル筋形，起始部二近キ

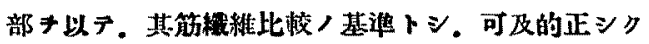

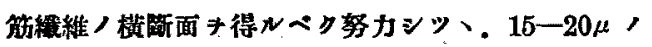
麽廿二切片キ作レツ。

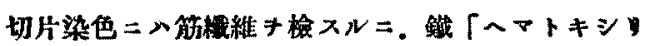

第 一 表

\begin{tabular}{|c|c|c|c|c|}
\hline & 龄 & 性 & 死 & 榮㐙肰憼 \\
\hline 11 & 歲 & 男 & 肺 結 楼 & 稍 良 \\
\hline 16 & 茷 & 男 & 不 明 & 不 明 \\
\hline 19 & 歳 & 男 & 肺 緢 秋 & 㮐 良 \\
\hline 25 & 戙 & 男 & 結䄈性腹膜炎 & 不 良 \\
\hline 80 & 筬 & 侽 & 肺 結 柆 & 不 良 \\
\hline 39 & 䇺数 & 男 & 肺 結 核 & 稍 点 \\
\hline 45 & 箴 & 男 & 肺 結 核 & 稍 良 \\
\hline 51 & 战 & 男 & 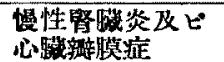 & 稆 良 \\
\hline & 戴 & 男 & 肺 結 核 & 稍食 \\
\hline 64 & 载 & 男 & 急性挡复卖炎 & 䅌 良 \\
\hline 70 & 蒇 & 男 & 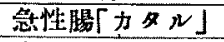 & 不良 \\
\hline 80 & 蒇 & 女 & 老要 & 稍 良 \\
\hline 84 & 藏 & 女 & 竞 & 不良 \\
\hline
\end{tabular}

ン法(Heidenhein). 彈力䄉維キ检入Nタメ ゾルチン・フクシン」法(Weigert)。一般結䋨織キ棯 スルタメ Azan 法(Heidenhein) *用七タy。 


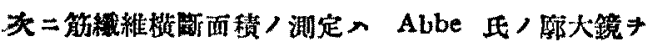

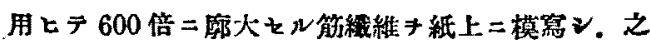

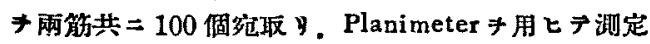
セり。面シテ筋瀻維ノ選摆二關シテッ，可及的主猚

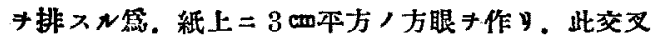

\section{第三草检查成 辚}

\section{第一菂 䈃㵶維橫斷面/形狀}

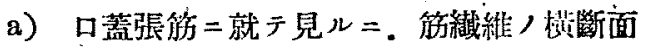
八幼若ナルモノ＝於テハ多ク八類圆形ナルガ.

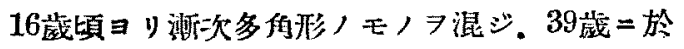
テ八㱠ド多解㘍維ノ、ョリナル。然レドモ 濑次老年ニナル二從と，再ビ其形䊿ノ多的形ナ ルモノ減シ類圆形ノモノ堽加ス。而シテ之等各

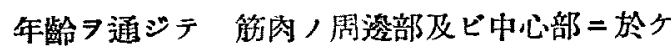

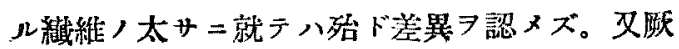
$=$ Wohlfart 八人及ビ數種，哺乳䄱物，眠管 ，年龄的變化 7 研究シ.年路，篔加スル 筇原瀻維 /減少=伴フ肉獎，增加 7 指摘七ルガ

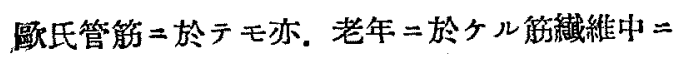
八. 若年ノモノ二比シ比較的筋原纎維減少シ. 肉整ノ增加セルモノアルラ認メ得。

b) 口真擧筋二就テモ口蓋張箈卜略

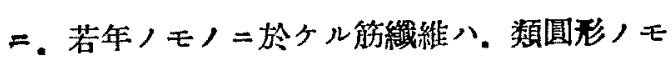
ノ、多角形ノモ，互二混ズ。而シテ年齡，增扣 卜共二多角形ノモノ管扣シ．類圆形ノモノ、減 少スル＝對シ，老年ノモノ二至以テハ㴬次類圆 柇ノモノ墦加シ柬引リ 84 歲=於テ八砝ド圆形 ノ泣トル。

而シテ本箈ニ於テハ，若年．中年ノモノ二於テ 八其周港部卜中心部 7 比較シテ，其繊維ノ太サ 二然程差異ヨ認メザルモ. 老人ノモノニ於テ，

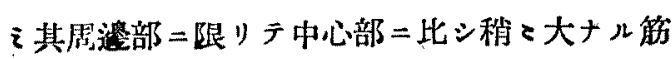

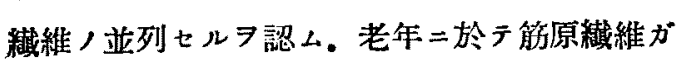

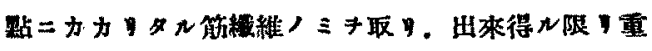

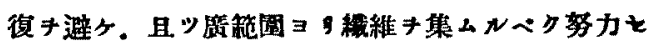
yे。

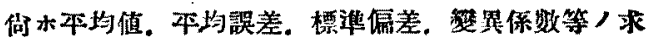
メ方メ足立八記载二從へリ。

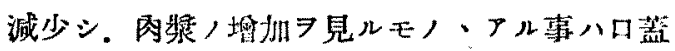
張筋二同ジ。

\section{第二笝 族 維 維 / 數}

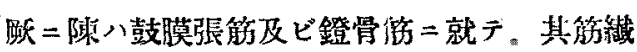

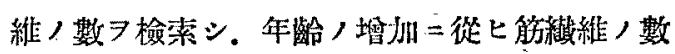

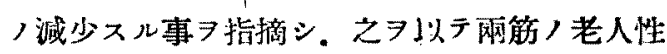
變化ノーツナリト說ケリ。

余モ亦第二表二示ス如ク， 口蓋張施及ビ口蓋舉 筋二就テ其箊瀻維，數 數八丽缼共二。幼若ナルモノ二於テ最モ多ク約

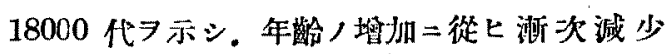
ス. 例人バ口蓋張筋三於テハ 84 歳=於テ 9948 ニシテ，16藏ノモノ、殆ド牛數二近シ。而シテ

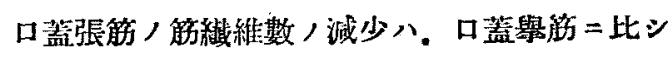
稍

$$
\text { 第 二 表 }
$$

\begin{tabular}{|c|c|c|c|}
\hline 口蓋㖘筋 & 筋織維維数 & 口蓋䋈筋 & 筇樴維數 \\
\hline 16 藏 & 18761 & 16 蔵 & 18290 \\
\hline 25 墭 & 14184 & 25 藏 & 15521 \\
\hline 39 蔵 & 16424 & 39 盛 & 14709 \\
\hline 45 藏 & 16603 & 45 歲 & 15026 \\
\hline 56 筬 & 14324 & 56 蔵 & 14467 \\
\hline 70 筬 & 12687 & 70 咸 & 14024 \\
\hline 84 澸 & 9948 & 84 藏 & 13035 \\
\hline
\end{tabular}

\section{第三節 筋維維/平均横藏面棈}

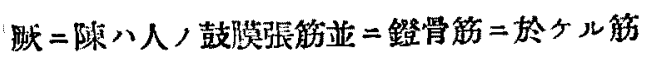
維維，平均横斷面積 成績=ヨレバ. 雨筋八共 $=15$ 歲乃至 35 歳 $=$

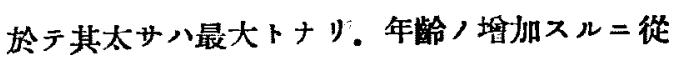


七其太サ，減少スル事．特=鼓膜張筋＝於テ其 減少度, 著シキ事ョリシテ 彼八夫等雨筋，老 人性變化 7 指摘シ。特=鼓獏张筋八鐙骨筋二比 シ老人性變化著明ナリトセリ。

余モ亦第三表及ビ第四表二示ス如ク，品真张筋

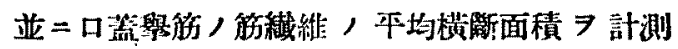
シ. 幼若ナルモノ＝於テハ其太サハ小ニシテ.

$$
\text { 第三表 口蓋張筋 }
$$

\begin{tabular}{|c|c|c|c|c|}
\hline ff & 㗉 & $M+m$ & $\sigma$ & $\mathbf{V}$ \\
\hline 11 & 龀 & $2.04 \pm 0.07$ & 0.73 & 35.8 \\
\hline 16 & 域 & $3.35 \pm 0.14$ & 1.37 & 40.9 \\
\hline 19 & 战 & $3.98 \pm 0.13$ & 1.34 & 33.7 \\
\hline 25 & 䠃 & $3.97 \pm 0.16$ & 1.55 & 39.0 \\
\hline 30 & 㭰 & $4.8 \pm \pm 0.19$ & 1.92 & 39.7 \\
\hline 39 & 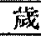 & $5.03 \pm 0.18$ & 1.84 & 36.6 \\
\hline 45 & 盛 & $3.98 \pm 0.14$ & 1.36 & 34.2 \\
\hline 51 & 䑺 & $3.75 \pm 11.16$ & 1.61 & 42.9 \\
\hline 56 & 踥 & $3.60 \pm 0.15$ & 1.52 & 42.2 \\
\hline 64 & 战 & $4.08 \pm 0.16$ & 1.62 & 39.7 \\
\hline 70 & 站 & $3.90 \pm 0.12$ & 1.19 & 30.5 \\
\hline 80 & 荿 & $3.58 \pm 0.16$ & 1.57 & 43.9 \\
\hline 84 & 诚 & $3.04 \pm 0.13$ & 1.28 & 42.1 \\
\hline
\end{tabular}

第四表 口蓝舆筇

\begin{tabular}{|c|c|c|c|c|}
\hline 年 & 战合 & $\mathrm{M} \pm \mathrm{m}$ & $\sigma$ & V \\
\hline 11 & 媙 & $3.82 \pm 0.15$ & 1.52 & 39.8 \\
\hline 16 & 䄳 & $5.01 \pm 0.18$ & 1.80 & 35.9 \\
\hline 19 & 原 & $5.82 \pm 0.17$ & 1.68 & 28.9 \\
\hline 25 & 旊 & $5.56 \pm 0.23$ & 2.29 & 41.2 \\
\hline 30 & 战 & $7.03 \pm 0.23$ & 2.34 & 33.3 \\
\hline 39 & 嵅 & $7.32 \pm 0.16$ & 1.58 & 21.6 \\
\hline 45 & 葴 & $6.48 \pm 0.16$ & 1.61 & 24.8 \\
\hline 51 & 歳 & $5.55 \pm 0.19$ & 1.92 & 34.6 \\
\hline 56 & 蔵 & $5.27 \pm 0.21$ & 2.06 & 39.1 \\
\hline 64 & 㟵 & $4.82 \pm 0.15$ & 1.49 & 30.9 \\
\hline 70 & 筬 & $4.46 \pm 0.16$ & 1.64 & 36.8 \\
\hline 80 & 藏 & $5.12 \pm 0.19$ & 1.88 & 36.7 \\
\hline 84 & 歳 & $3.90 \pm 0.16$ & 1.58 & 40.5 \\
\hline
\end{tabular}

39歲ノモノニ至リテ最大トナリ。老年ニナルニ 從ヒ漱次小トナル事 7 認メタリ。例人ハ口葢张

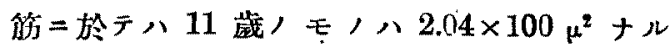

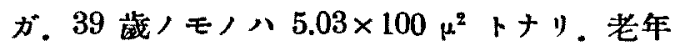
ニ於テハ再ビ小トナり。84歳ノモノデハ $3.04 \times$ $100 \mu^{2}+y 。$

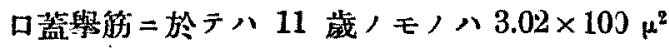

ナルが. 39 歳ノモノニ於テハ7.03 ×100 $\mu^{2}$ ナソ. 84 歳二於テ, $3.90 \times 100 \mu^{2} ト+ル 。$ 其變位係數二就テハ，中年，示比較シ老年

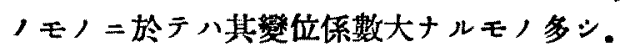

第 五表

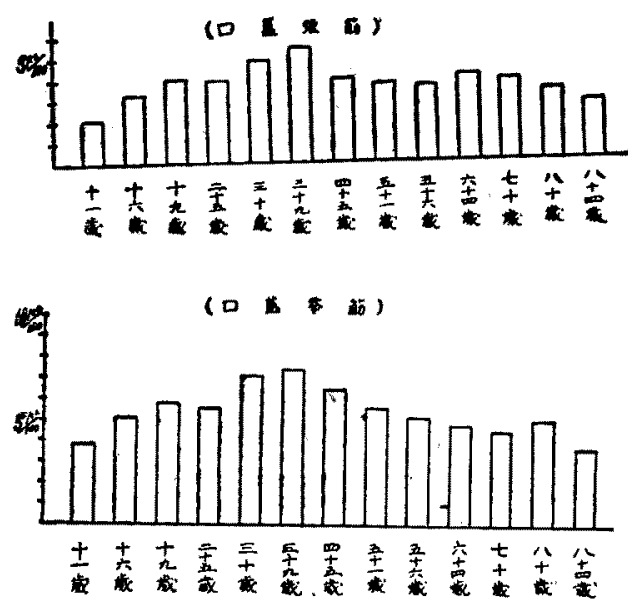

第四蒒 第二節及ビ第三䇫ニ於ケル 檢查 /综合成績

以上第二䇫及ビ第三節 $=$ 於々ル检查成績 合スル意味 =於テ 今假り二各年龄 $=$ 於ケル皦

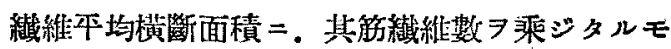
ノラツテえヨ琵ハスト七バ，第六表二示セル如 キ曲線 7 得。郎チ紀年及ビ中年ノモノ=於テハ 其曲線二變化尠ク．老年=至ル =及ビ著明 =其 曲線ノ低下スルフ認メタリ。

\section{第 六 表}

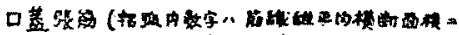

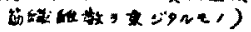

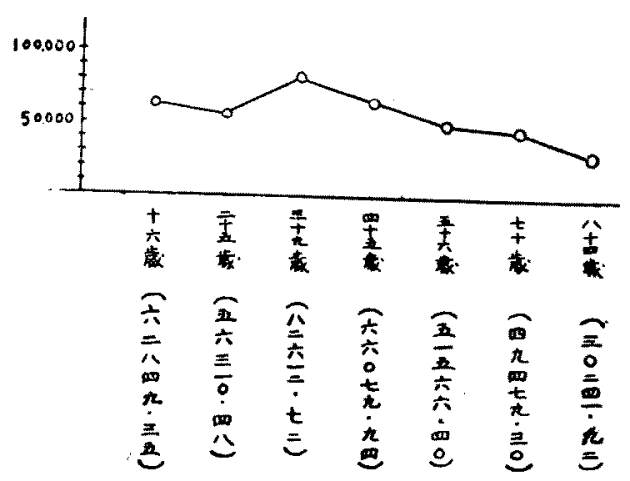




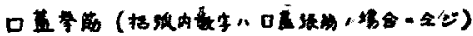

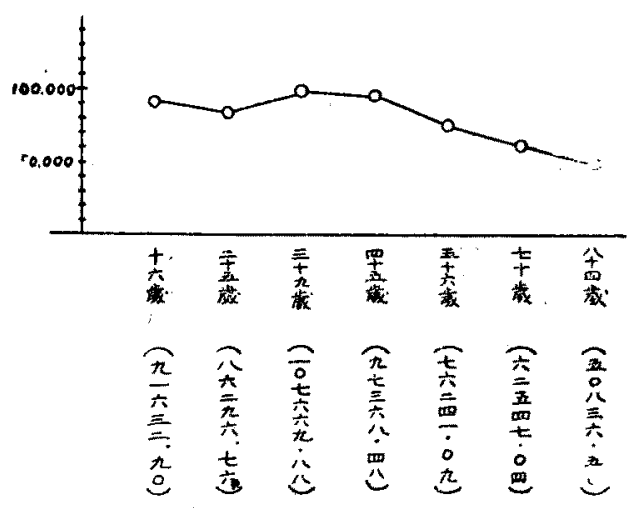

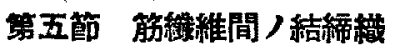

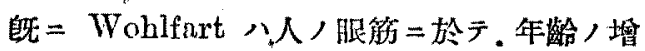
加スル二從七. 觔繊維間，結締織，增加スル事 ヨ以テ.筋肉ノ老人性變化ノ一ナリト考へタり。

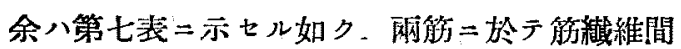
第 七 表

\begin{tabular}{|c|c|c|c|c|c|}
\hline & & 口 蓋 & 張 筋 & 口盐 & 舉 筋 \\
\hline 年 & 踥会 & 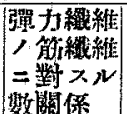 & 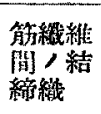 & 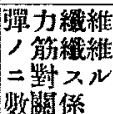 & 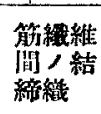 \\
\hline 11 & 減 & 0.2 & + & 0.6 & + \\
\hline 16 & 蔵 & 0.4 & + & 0.6 & + \\
\hline 19 & 减 & 0.4 & H & 0.4 & H \\
\hline 25 & 䉞 & 0.6 & + & 0.7 & $H$ \\
\hline 30 & 成 & 0.5 & H & 0.4 & H \\
\hline 39 & 筬 & 0.8 & $H$ & 0.6 & $\#$ \\
\hline 45 & 媙 & 0.5 & + & 0.6 & $\mathrm{HH}$ \\
\hline 51 & 藏 & 0.3 & $H$ & 1.0 & $\#$ \\
\hline 56 & 嵗 & 0.3 & $\#$ & 0.6 & $\mathrm{HI}$ \\
\hline 64 & 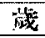 & 0.5 & + & 0.7 & $\mathrm{Ht}$ \\
\hline 70 & 歲 & 0.4 & HI & 0.7 & H \\
\hline 80 & 輱 & 0.5 & \# & 0.5 & 业 \\
\hline 84 & 筬 & 0.2 & + & 0.4 & HI \\
\hline
\end{tabular}

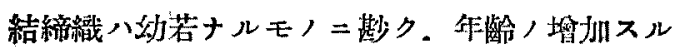

二從七堽加スルモノナル事フ認メタリ。而シテ

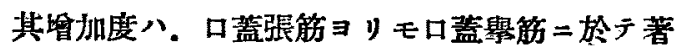

\section{第六蒠 彈力 織 維}

彈力緎維ハ「レゾルチン・フクシン」染色 $=$ ヨ

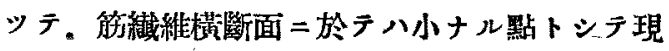
ハレ. 其表面 =放着シ又筋瀻維束間ノ結締織中 二モ存在

彈力纎維二就テハ、嗍二小橋ハ人體，種々ナル 骨骼筋二於テ之ヨ检菜シ，又除八鼓膜張笳及ビ

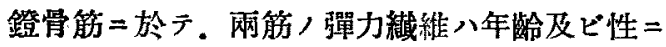
八關係無ク 個人 $=ヨ リ テ$ 異ナルモノナリト述 ベタリ。

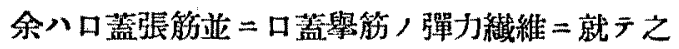
フ检索セル二(第七表). 小橋ノ檢索七ル種々ナ 几骨骼筋ノ夫レ二比シ。比較的其数八尠り 又 年齢的二著明ナル變化認メザリキ。

\section{第七節 脂 眆 組 織}

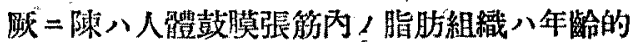
二蹾化シ．老年 $=$ 於テハ極メテ多量ナル脂肪組 織ノ存在スル事ヨ認メタリ。

余ハ口蓋張筋及ビ口蓋舉筋, 脂肪組織 =就テ之

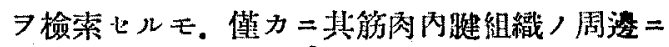
脂肪組織 7 少量認ムルノ $\bar{i}$ 。文年路，增加 $=$ 從 七著明ナ几增減無シ。但シ筋闪外，脂肪組織二 就イテハ. 各觔肉 7 周圍組織ヨリ離斷シテ檢卖 セシタメ。えニ關シデハ不明ナリ。

\section{第二 篇 人體ノ莖狀舌筋並二茎狀咽頭筋二就テ}

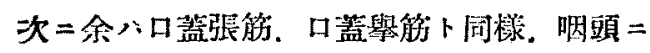

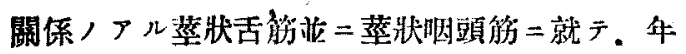

龄別 = 組織學的檢素习行ヒ. 解，歐氏管等 $=$ 比 較シ揤カ與味アル結果ア得タリ。 


\section{第一卖 兩荕ノ解剖學的䀦係}

蕉狀舌筋八茎狀突起 $ヨ$ リ始マリ，前下方二進 壬舌骨舌筋，側方二於テ $2 \%$ ，筋束=分離ス。 而シテ側上方，筋束八舌尖端=向七テ進 $i$.内 下方，筋束八舌骨舌筋 7 貫通シ舌，後部 = 问七 テ走n。
其作用八舌特 $=$ 舌根 7 後上方二率引ス。

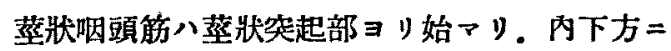
走り咽頭壁二於テ中咽頭收縮筋二分散ス。其作 用八咽頭 援大シ咽頭及ビ呢頭フ舉上ス。

\section{第二革财料及ビ检查方法}

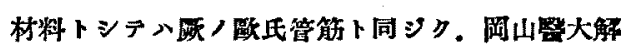

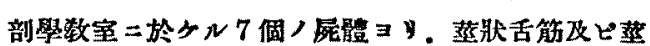
狀咽頭筋キ璪取七、。

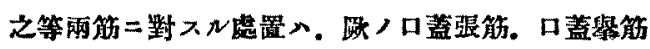
二於ヶル場合卜略了同栐ナソ。但シ雨筋共二，其起

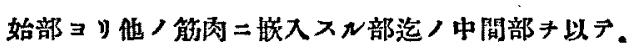

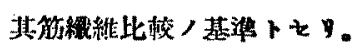

\section{第三章}

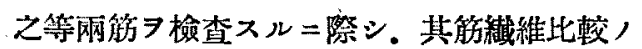
基準 7 定ムル

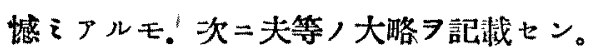

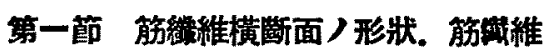

間結縓織並二彈力纎維ニ就テ

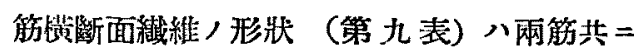
第九表

a) 经狀舌筋

\begin{tabular}{|c|c|c|c|}
\hline & 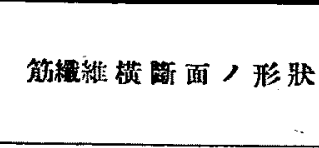 & 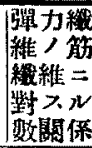 & 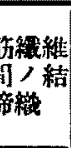 \\
\hline 19紫 & 冬クハ多解形ナリ。 & 1.3 & + \\
\hline 39筬 & 多ク八多角形ナリ。 & 1.2 & + \\
\hline 51媙 & 多角形及ビ類跑形ナソ。 & 1.0 & $H$ \\
\hline 64战 & 殆ンド類圆形ナツ。 & 1.2 & + \\
\hline 70戎 & 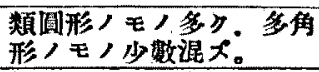 & 1.2 & $H$ \\
\hline 84䈅 & 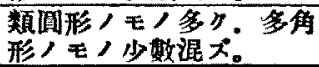 & 0.8 & $H$ \\
\hline
\end{tabular}

第入表

\begin{tabular}{|c|c|c|c|c|}
\hline 年 & 㵙 & 性 & 死 & 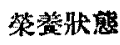 \\
\hline 19 & 踐 & 䙲 & $\begin{array}{ll}\text { 肺 結 } \\
\end{array}$ & 稍 \\
\hline 39 & 蔵 & 男 & 肺 結 核 & 稍 \\
\hline 51 & 葴 & 男 & 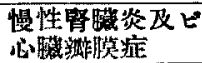 & 雬 \\
\hline 64 & 筬 & 男 & 急性氣管支炎 & 稍 \\
\hline 70 & 荿 & 男 & 等性腸「力タ & 不 良 \\
\hline 84 & 嵗 & 女 & 老 襄 & 不 良 \\
\hline
\end{tabular}

檢查成 績

b) 缘狀咽頭筋

\begin{tabular}{|c|c|c|c|}
\hline & 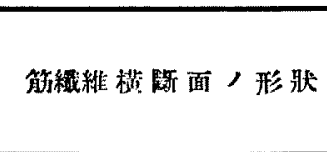 & 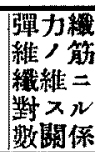 & 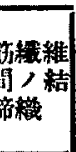 \\
\hline 19歳 & 類泪形及ビ多角形ナり。 & 1.4 & $H$ \\
\hline 39葴 & 多クハ多解形ナリ。 & 1.5 & + \\
\hline 51歲 & 類践形ノモ，多シ。 & 1.2 & \# \\
\hline 64葴 & 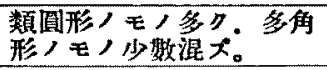 & 1.2 & H \\
\hline 70歲 & 殆ンド類回形ナッ。 & 1.4 & \# \\
\hline 84歲 & 殆ンド類四形ナリ。 & 1.2 & $H$ \\
\hline
\end{tabular}

19歲. 39 歲=於テハ多ク八多角形ニシテ. 年龄 人增加二從七類圆形ノモノ、增加

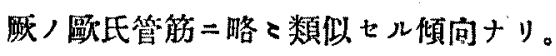
箊絒維間結縍織八(第九表)䓠狀舌筋二於テ八若 年. 中年，モノ=比較シ老年二於テ八耧分增加 セル如キ感アルモ。蕉狀咽頭筋二於テ八必ズシ 
モ然ラズ。

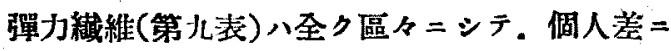
因ルモノナリト若フルョリ外ナシ。

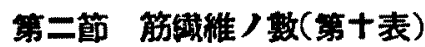

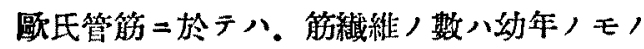
二多ク．年龄，增㧈ト共二泚次減少セリ。

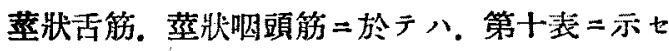
ル如ク區タナリ。

第十表箶程維

\begin{tabular}{|c|c|c|c|}
\hline 年 路会 & 性 & 蒸狀舌筋 & 莖牀咽頭筋 \\
\hline 19 盃 & 男 & 9799 & 7517 \\
\hline 39 媙 & 男 & 17424 & 16400 \\
\hline 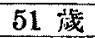 & 男 & 12687 & 14244 \\
\hline $6 \pm$ 墄 & 罗 & 11706 & 9492 \\
\hline 70 成 & 篹 & 13255 & 12645 \\
\hline 84 战 & 女 & 12522 & 10171 \\
\hline
\end{tabular}

第三節 荕維維ノ平均横斷面積

$$
\text { （苇十一表） }
$$

趺，歐氏管"二於テハ. 幼若モ，二於テハ其 價小サク、39政ノモノ二於テ最高二達シ。老年 ニ至ル＝文ビ再ビ小トナル。陳ガ鼓膜張筋。鐙骨

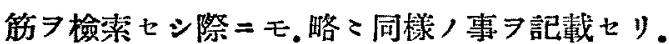

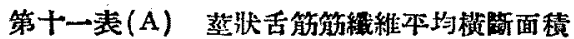

\begin{tabular}{|c|c|c|c|c|c|}
\hline 年 & 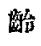 & 性 & $\mathrm{M} \pm \mathrm{m}$ & $\sigma$ & $\mathrm{V}$ \\
\hline 19 & 旅 & 男 & $3.48 \pm 0.14$ & 1.43 & 41.1 \\
\hline 39 & 葴 & 男 & $5.42 \pm 0.20$ & 1.99 & 36.7 \\
\hline 51 & 歲 & 男 & $5.21 \pm 0.10$ & 0.98 & 18.8 \\
\hline 64 & 䈅 & 男 & $5.59 \pm 0.27$ & 2.74 & 49.0 \\
\hline 70 & 歳 & 男 & $6.25 \pm 0.21$ & 2.14 & 34.2 \\
\hline 84 & 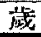 & 女 & $5.95 \pm 0.27$ & 2.65 & 44.5 \\
\hline
\end{tabular}

第十一表 (B) 䔲狀咽頭筋筋䄉維本均横断面栍

\begin{tabular}{|c|c|c|c|c|c|}
\hline 年 & 鲾合 & 性 & $M \pm m$ & $\sigma$ & $\mathbf{V}$ \\
\hline 19 & 媙 & 男 & $6.18 \pm 0,07$ & 0.70 & 11.3 \\
\hline 39 & 瓷视 & 男 & $6.93 \pm 0.11$ & 1.07 & 15.5 \\
\hline 51 & 筬 & 男 & $6.84 \pm 0.20$ & 2.02 & 29.5 \\
\hline 64 & 茂 & 男 & $6.44 \pm 0.18$ & 1.84 & 28.6 \\
\hline 70 & 歳 & 男 & $5.92 \pm 0.10$ & 0.95 & 16.1 \\
\hline 84 & 歳 & 女 & $6.25 \pm 0.15$ & 1.46 & 23.4 \\
\hline
\end{tabular}

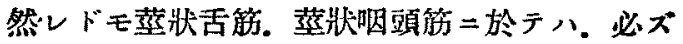
シモ然ラズシテ 各年齡
シ認メザリキ。

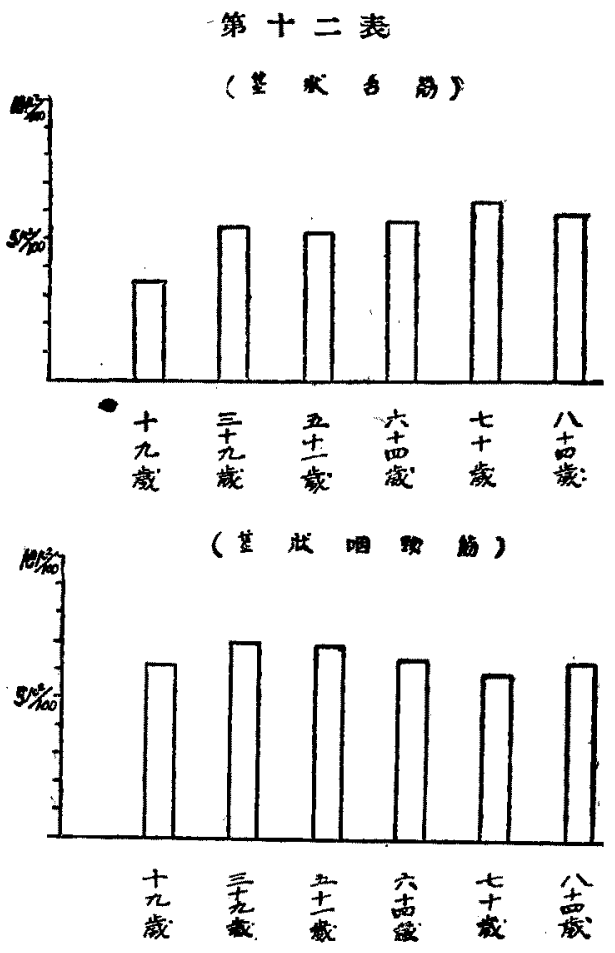

第四節 第二萁及ビ第三苔ニ於ケ几 檢査ノ綄合成樍

㷧二跃氏管筋二就テ示七ル如ク．以上第二 及ビ第三節

$$
\text { 第 }+ \text { 三表 }
$$

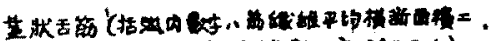

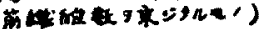

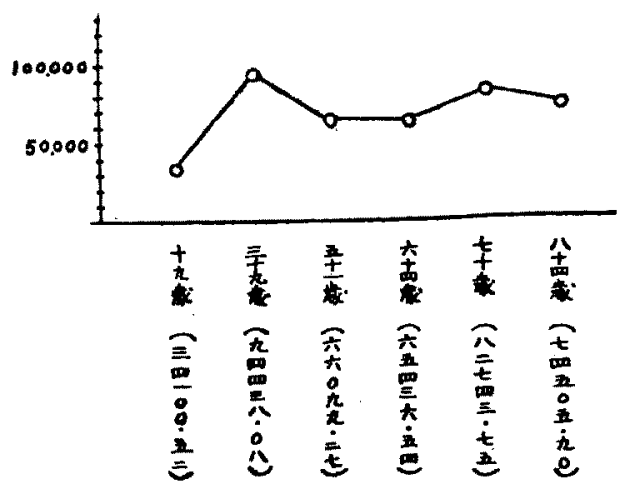




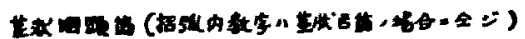

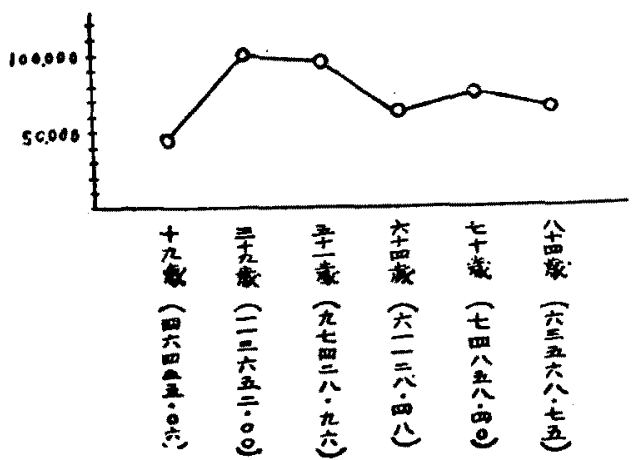

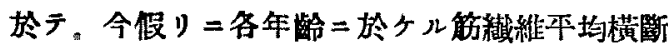

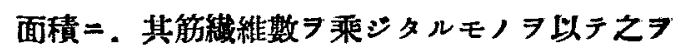
表ハスト七パ. 第十三表二示七ル如キ曲線 得。

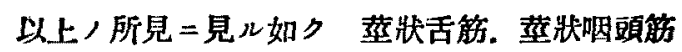

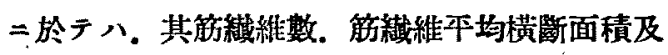

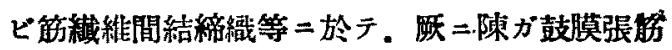
二於テ 双余が歌氏管解二於テ認メタルガ如キ 著明ナル老人性變化ハ概シテ認メ得ザル如シ。

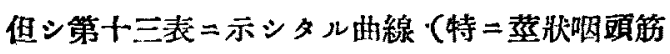
，曲綵）＝關シテハ。老人二於テ可ナリ曲線， 低下七ルョ認メ得。

按

㓹二モ远ベシ如ク正常ナル人二於テ八，歌氏

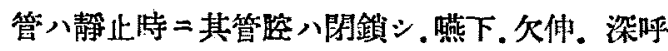
吸等ノ際ニ初メテ其開大 7 觀. 依ッテ中耳啌卜

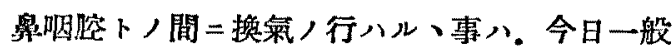
諸家ノ㸉シク認ムル所ナルガ. 若シ一医其管㬵

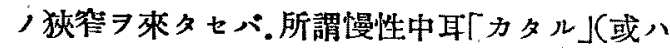

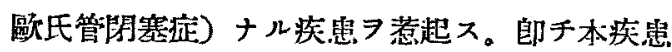
八區氏管狄害，絬呆. 生理的=行ハル、べキ舅

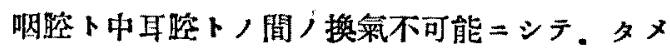

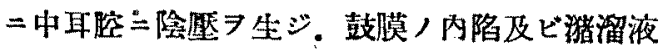
’出現 7 見ル二至ルモノナリ。從シテ本疾患二

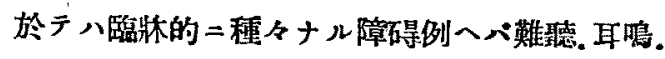

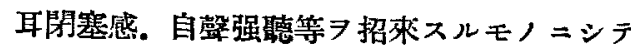
我が耳學胭喉科 7 訪レル全耳疶患々者ノ約 15.0

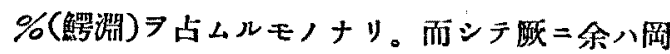

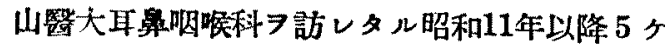
年閒/本获患々者ノ統計的覞察习行七。本症八 小兒二於テ八腺㴚增殖往。的カタル等ノ本症 ノ誘因ト思ハル、モノアリテ現ハル、真多キ=
默シ。老人二於テ八何等誘因ト思ハル、モ/無 クシテ 然モ頑固ナル本拝患者二遭遇スル事䵇

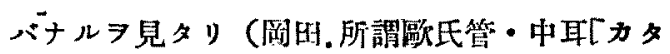
ル」統計的観祭)。

從來一般二本症，原因トシテハ：

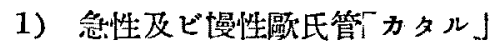

2) 腺椂增殖症

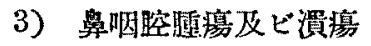

4) 跃区管等 / 麻脌

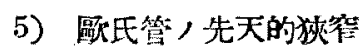

等ガ舉がラル。

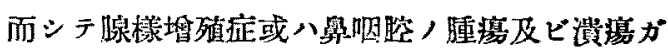

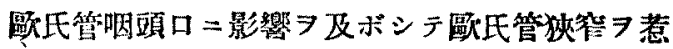

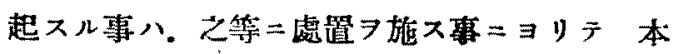
掟ノ洽劄

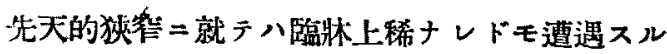
所ナリ。次二碿氏管「カタル」=ヨル區氏管狹错

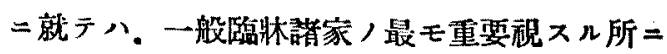
シテ 管脱二炎应，存在スル場合ハ斪論ナルモ。 例命其炎症ガ消退七シ挠二モ，歐氏管粘膜八肥 


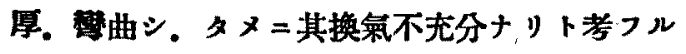
舆者多シ。

然レドモ Mink ハ本疾患二對シテ歌氏管通氣。 「ブジールンク」等 7 行つモ充分ナル效果ノ現八 レザル事三注目シ，又歐氏管通拣.「プジールン クコニヨリ其管腔八一時開通ヨ見ルモ又速カ 閉鎖スル事ヨリシテ 歐氏管，塽管八歐氏管粘

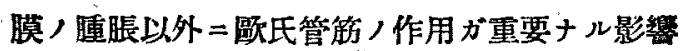
ア及ボス事习指摘セリ。郎于彼八口蓋張施が歌 氏管膜様部二於テ其管腔二向七隆起スル事 $コ$ シテ 該筋，菣張ガ富マレバ其膨隆，減退二ヨ リ歐氏管腔八開大シ，其繠張が減ズレバ管腔八 狄小トナルモノナリト說ケリ，Gyergry モ亦 歐氏管生理 7 研究シ。跃氏管规管，直接，原因 八炎掟或八管腔ノ形態ノ變化二因ルト云フョリ モ蜜口歐氏管筋，機能減退二因ルモノナリト說 ケリ。即于彼八歐氏管通氣，不可能ナル場合二 於テ，該筋二電氣刺战其他 7 施セ八歐氏管缼 機能八高マリ．歐氏管ノ開通 7 見ルモノナリト 述べタリ。文安藤八正常並二歐氏管筇/機能 7

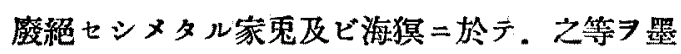
汁中=溺死七シメテ歐氏管，通過狀態 7 研究七 ルガ.正常ナル動物二於テ八溺死ノ際。與下作用

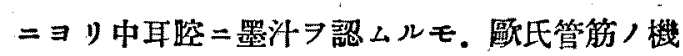
能 7 廢釈七シメタル重物二於テハ.中耳腔二墨 汁フ證明セザリシ事苗ヨリシテ、彼八歐氏管， 通過障碍八其炎症性形態䛓化ノ外二，歐氏管能 ノ機能減退ヨ以テセザレバそフ說明シ難シト說

\section{第五章結}

1) 余八人體歐氏管筋，組織學的研究。 及ビ

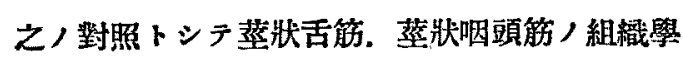
的研究ヨ行ヒタリ。 郎チ 11 歲ヨリ 84 歲=至ル
タリ・

然レドモ鰐罳ノ記載=ヨレバ. Siebenmann 八 臨牀的二器下筋 , 牛側完全麻疩

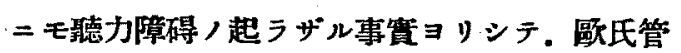
，關通八㰧氏管筋ノ作用ニノミ歸スべキャ否ヤ

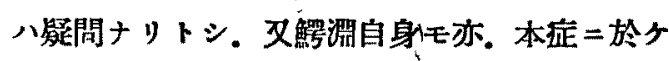
儿歐氏管筋，問題＝關シテハ. 種タナル原因二

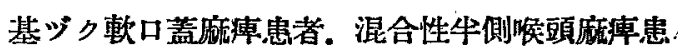
者. 口蓋破裂患者.上顎骨切除患者等二就 臨牃的二檢索七儿結果. 唯一例上顎骨全切除啳 ノ患者二頑固ナル歐氏管閉塞 卜述べ. 結局本問題, 解决八將來, 研究二侯》 ベキモノナラン乎ト言へリ。

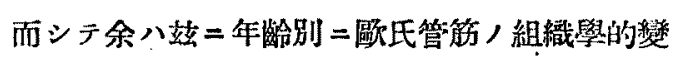
化

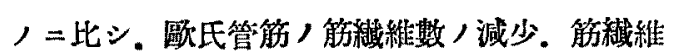

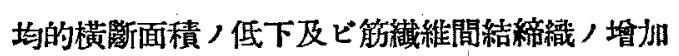
等ノ所謂筋肉ノ老人性勧化 舌筋. 蕉爿咽頭筋ト比較セル結果ヨリシテ 老 人二於ケル歐氏管筋ハ機能娍退 多キ事フ推察シテ可ナラン。

㟲 =モ述ベシ如ク臨牀上老人二於テハ，何等誘 因ト考へラル、モノ無クシテ。碩困ナル歐氏管

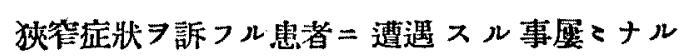
ガ. 此原因トシテ勿詥他二種かナル要因ア゙ラン モ. 茲二余ガ检索七儿歐氏管筋ノ老人性變化モ 亦. 其一要約ナラント洘フ。

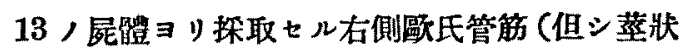
舌筋. 蕉狀咽頭䈌二於テハ7個，尼體ヨリ探取

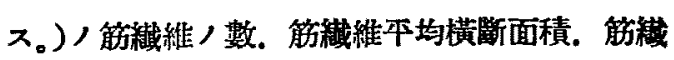




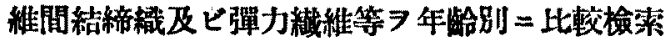
セり。

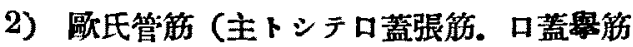

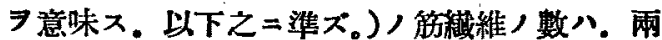
筋共二若年ノモノ二多り．年齡／增加スル二從 ヒ減少ス。例人吅蓋張筋ノ如キ入.84戴/モ 人、解繊維數ハ 11 歲ノモノ、夫レノ約牛數ナ y.

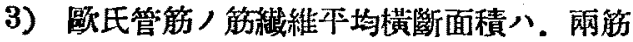
共二若年ノモノハ小ニシテ．年缺命，增加スル= 從七漱次大トナリ。39歲ノモノ二至りテ最高二 達シ.夫レヨリ老年トナル三從七其太羽減ズ。 例へバ口蓝張筋二於テハ.11歲ノモノニ於テハ $2.04 \times 100 \mu^{2}+ル カ ゙ ~ 39$ 歳二至レバ5.03 $100 \mu^{2}$ ト增大シ。次 $=84$ 藏ノモノ =於テ $3.04 \times 100$ $\mu^{2}$ ト縮小ス。

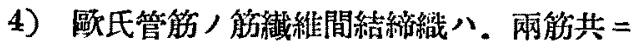

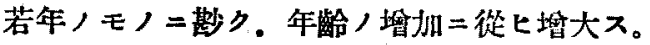
其增加/度ハ口蒀擧筇二於テ著明ナリ。

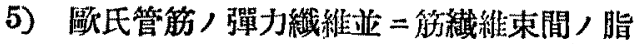
肪組糡二就テハ. 兩筋共二著明ナル戀化 7 認メ
ザリキ。

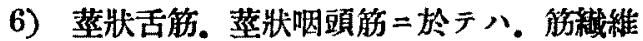
數八各年踰

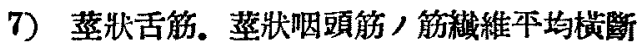
面積八。各年龄ヨ通ジテ著明ナル變化フ認メズ。

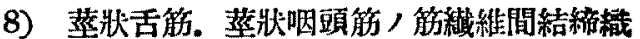

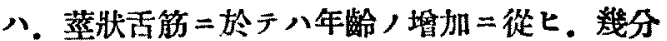
增加／傾向ジ見ルモ．莖状咽頭筋二於テハ必ス シモ然ラズ。

9）以上述ぺタル區氏管筋及ビ蕉狀舌筋。蕉 哭呁頭筋，組織學的檢素二於テ 老年=於ヶル 歐氏管筋が.若年ノモノ二比較シ.解繊維數/減 少，筋繊維平均横斷面積，減少，筋緎維間結締 織，增加等 管筇ノ機能減退ヨ示スモノナリト推察シテ可ナ

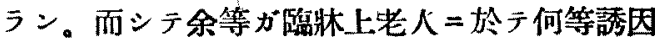
ト考へラル、モノ然クシテ，碩固ナル歐氏管狹 管患者二遭遇スル事屡をナルガ，其原因トシテ 八他二種々ナル要因フランモ。此歐氏管筋ノ老 人趾變化モ亦. 其一要約ナラント考つ。

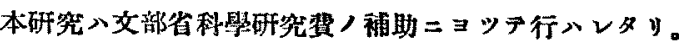

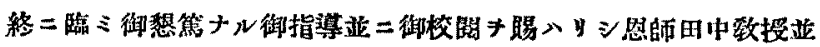

二小田教授二對シ。深基ナル謝意キ表スルト共二。枋料及ビ御数示

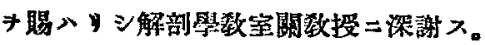




\section{文}

1) Rüidinger: Beitrăge zur Anatomie u. Histologie der Tuba Eustachii des Menschen deru: Saugetiere. Mschr. f. Ohrenheilk. Bd. 1, 18671869. 2) Tröltweh : Beiträge zur anatomischphysiologischen Würdigung der Tuben- u. Gaumenmuskulatur. Archiv f. Ohrenheilk. Bd. 1, 1864. 3) Rebeamen: Zur Mechanismus der Tuba Eustachii, Mschr. f. Ohrenheilk, Bd. 2, 1868. 4) voltolini: Ob die Tuba Eustachii des Menschen bestandig offen oder geschlossenist? Mschr. f. Ohrenheilk. Bd. 3, 1870. 5) Webex: Uber die Beziehung des M. levator veli zar Tuba Eustachii. Mschr. f. Ohrenheilk. Bd. 5, 1870. 6) Derselbe: Zur physiologie der Tuba Eustachii. Mschr. f. Ohrenheilk. 2, 1868. 7) Lu= cae: Zur Mechanismus des Gaumensegels u. der Tuba Eustachii. Archiv f. Ohrenheilk. Bd. 13, 1878. 8) Max. Manm: Uber Gaumenlăhmung. Zeits, f. Ohrenheilk. Bd. 47, 1904. 9) Eryant: Die Ohrtrompete, ihre Anatomie a. ihre Bewegungsapparate Archiv f. O. Bd. 72, 1908. 10) Politzer: Geschichte der Ohrenheilk. Bd. 1, 1907. 11) Spalteholz: Handatlas der Anatomic des Menschen. 1921-1929. 12) Mink: Die Massage der Ohrtrompete. Zeits. f. Ohrenheilk. Bd. 72,1915 . 13) Schelbe: Handbuch d. Hals- u. s. w. Heilk. (DenkerKabler) Bd, 7, 1926. 14)Gyergry: Verschiedene neue den physiolog. B-edürfnissen entsprechende Behandlungsarten der ungenügenden Ohrtrompetenlüftung der Mittelohrräume, Zentralb. f. H. N. u. O. Bd. 10, 1927. 15) Derselbe: Neue Wege zur Erkennung der Physio-

\section{fite}

Iogie u. Pathologie der Ohrtrompete. Mschr. f. Ohrenheilk. Bd. 66, 1932.

16) Bilnneiont, Gugllelmo, wario Sllvaggnl: Ober die Innervation der Muskulatur der Tuba Eustachii. Zentralb. f. H. N. u. O. Bd. 5, 1924. 17) Bemjamins n. Nienhnis: Untersuchung aber die Versuch von Valsalva u. Toynbee. Archiv f. $O$. N. u. KK. heilk. Bd. 117. 1928. 18) Wormu: Betrachtung über die Knorpelige Tube u. die Regio-pharyngo-tubaire. Zentralb. Bd. 30, 1938. 19) Wohlfart: Zur Kenntnis der Altersveranderungen d. Augenmuskeln. Zeitschr. f. mikroanat. Forschung. Bd. 44, 1938. 20) Kata: Uber histolog. Untersuchungen d. Augenmuskeln von Menschen u. Säugetiere. Okayama Fol. anat. Jap. 16, 1938. 21) Kohnsi: Histolog- Untersuchngen der verschiedenen Skelettmaskeln beim Menschen. Okayama, Fol, anat. jap. 151987. 22)吉井: 歐氏管ノ形狀及ビ大小二就テ，大日耳鼻

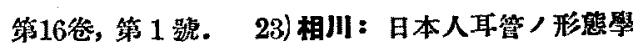

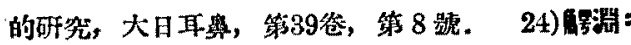

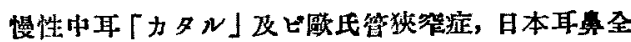

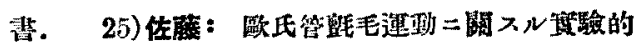

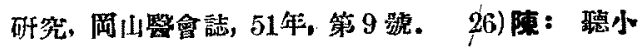

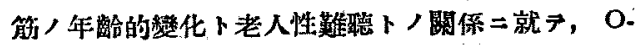
kayama Fol. anat. jap. 20, 1941. 27) 美田:

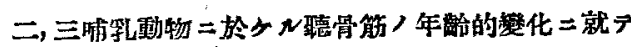

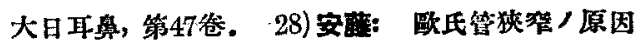

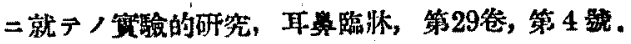

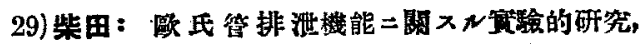

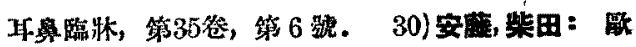

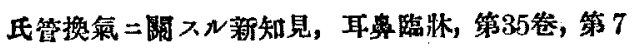
㫘。 
岡田文附圖

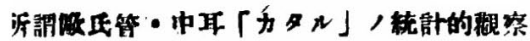
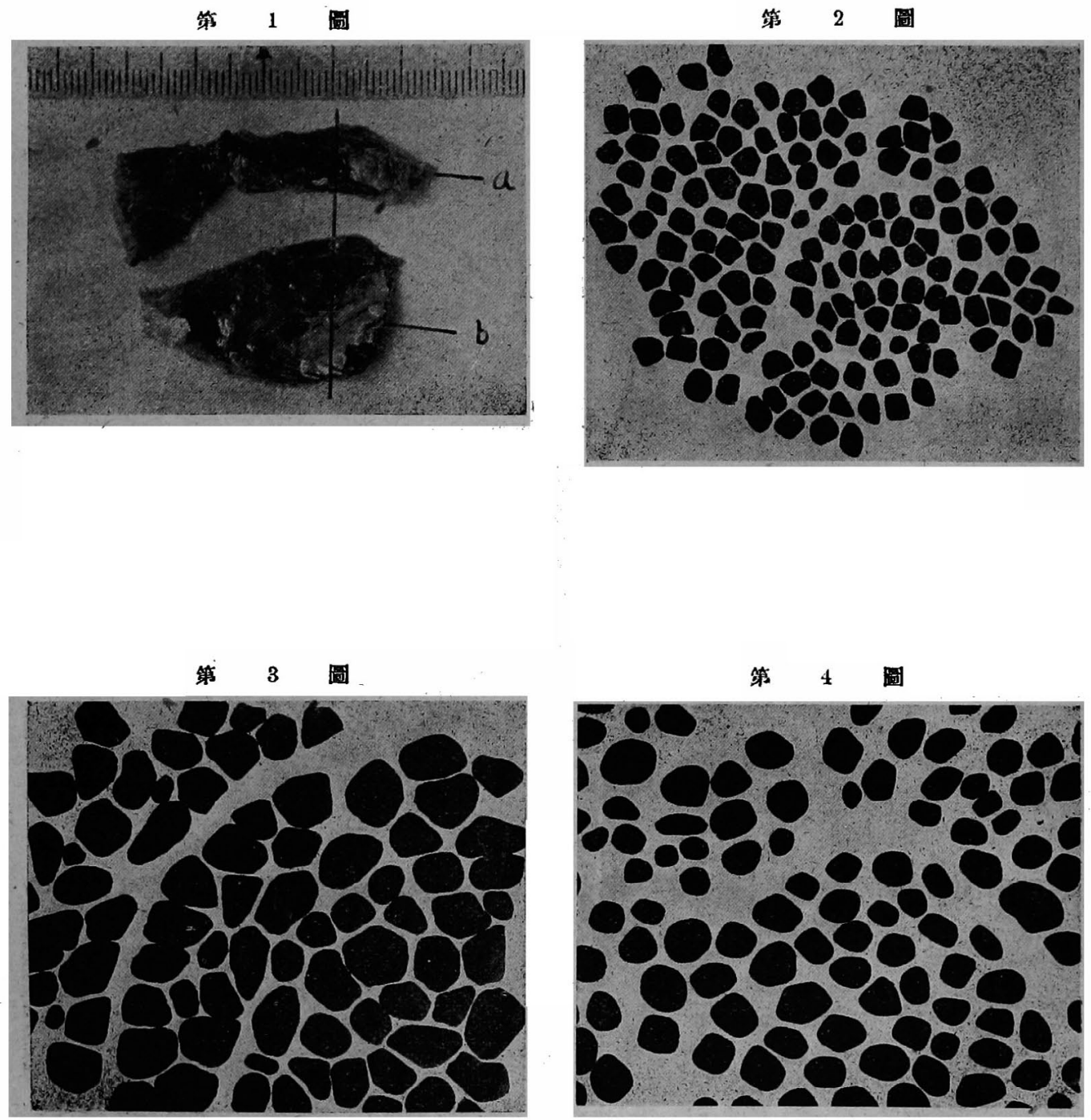

Dr. Kanrome okndas Óber den histologischen Bau von Tuhenmuskeln des Menschen. 


\section{网田馀文坿}

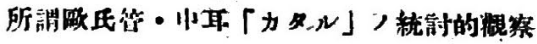
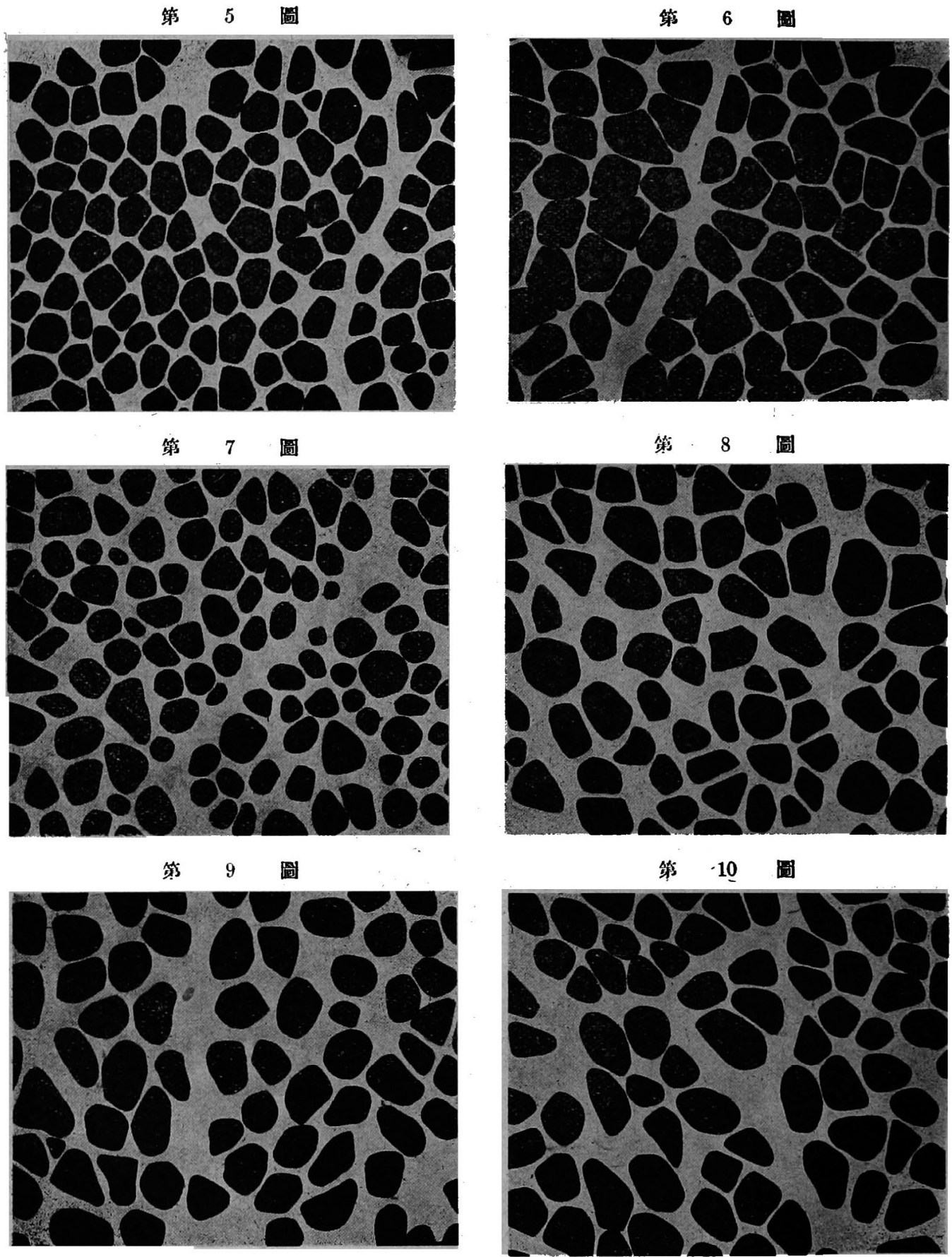

Dr. Kannme Oknda: Über den histologischen Bau von 'Tubenmuskeln -des Menschen. 


\section{岡田論文附圆}

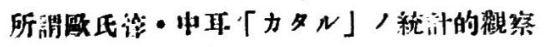

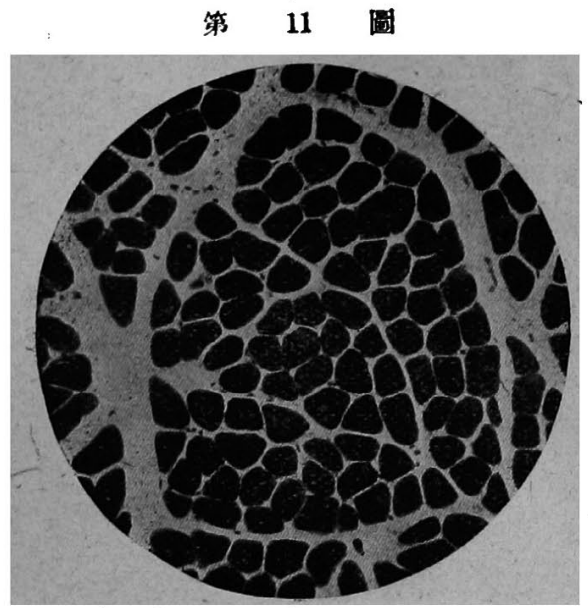

筷 13 圆

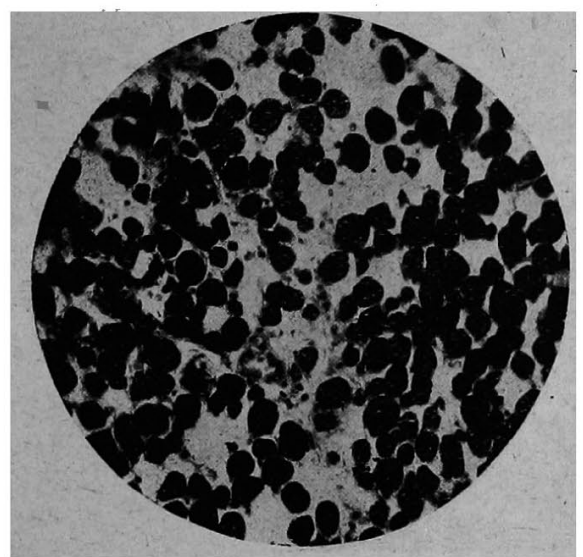

第 15 圖

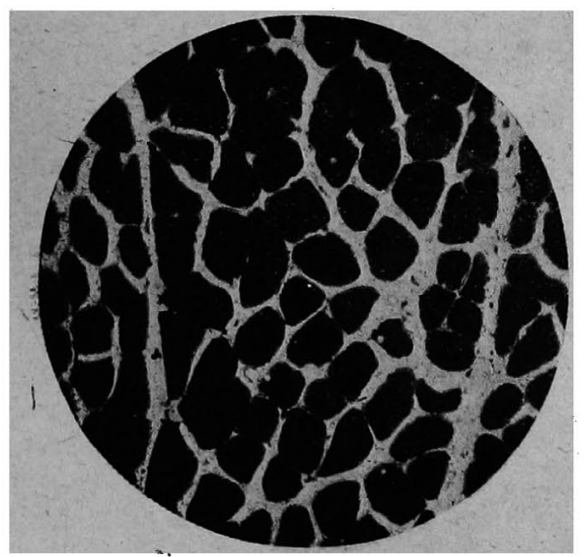

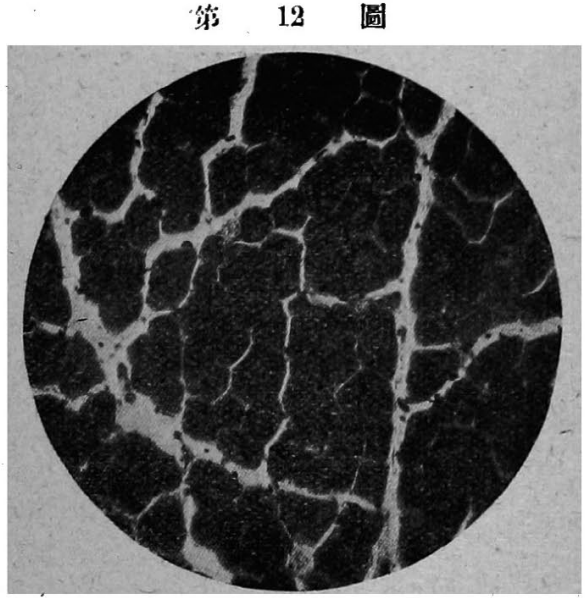

第 14 圆

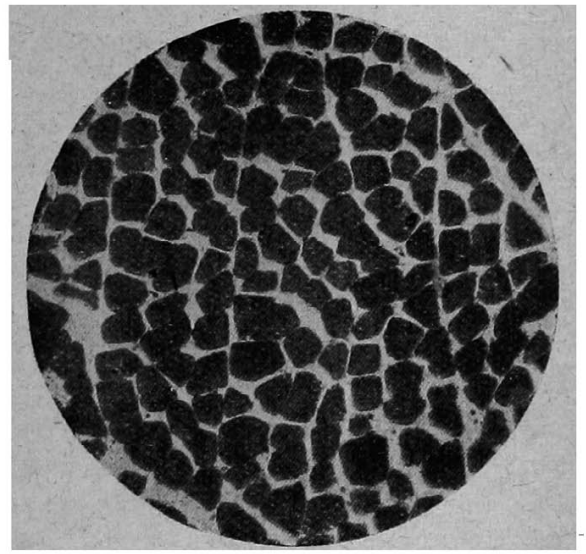

策 16 圖

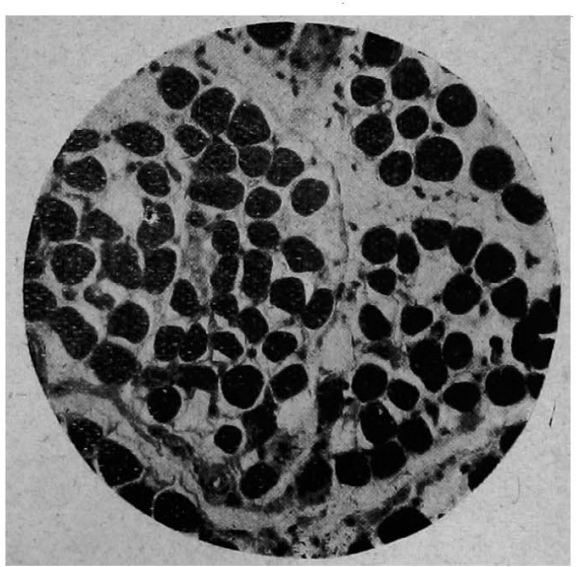

Dr. Knnsme Okadn: Ober den histologischen Bau von

Tubenmuskeln des Mensehen. 


\section{同田 諞 女 附 圖}

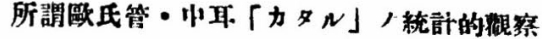

第 17 圆

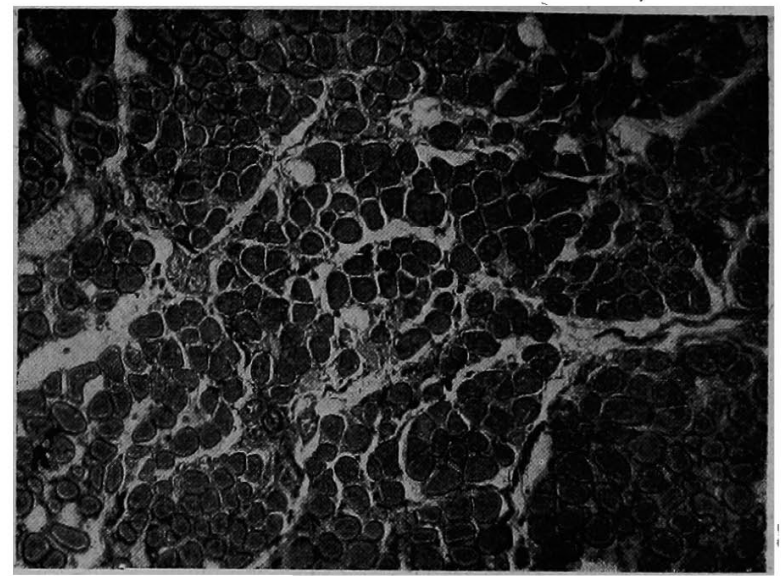

第 $18^{\circ}$ 圖

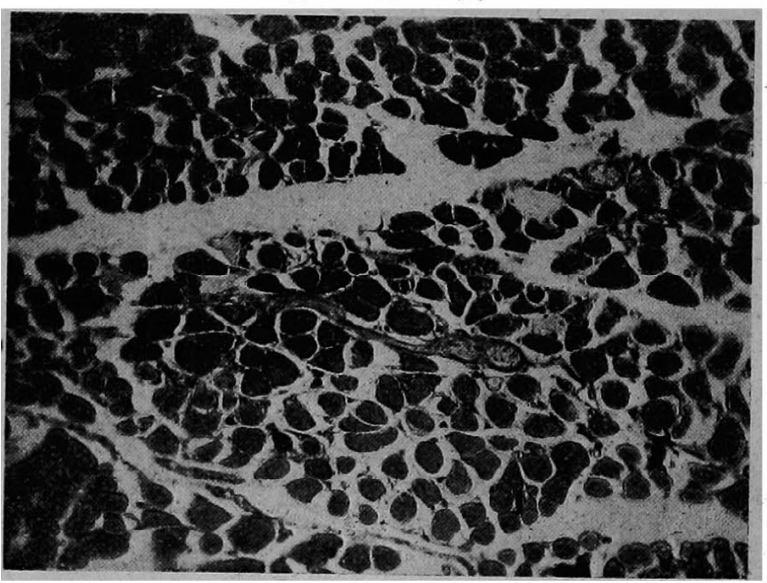

第 19 圖

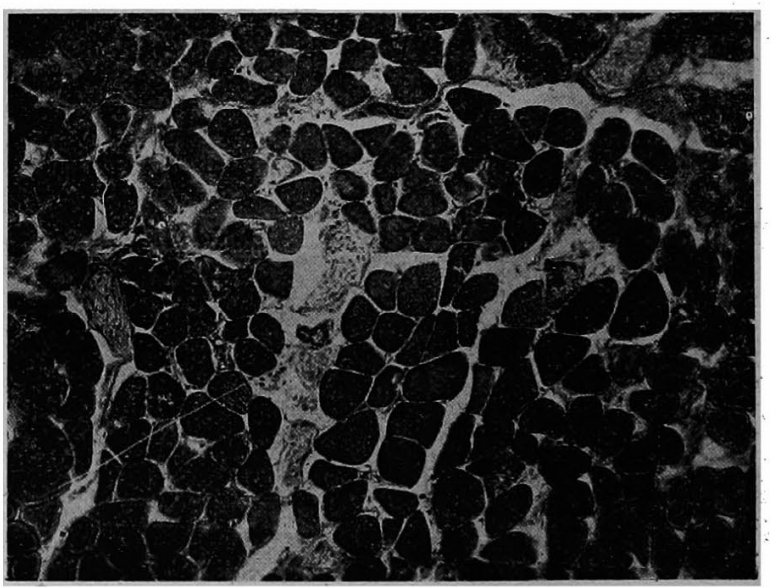

Dr. Knname Okada: Über den histologischen Bau von Tubenmuskeln des Menschen. 


\section{附圆毁 明}

第一圆人體歐氏管節

a. 口登藇筋 b. 口蓋张筋

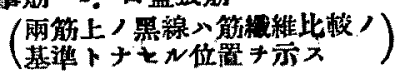

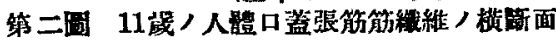
陁大 $200 x$

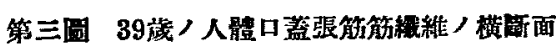
麻大 $200 \times$

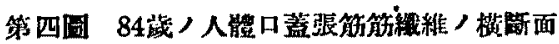
腒大 $200 x$

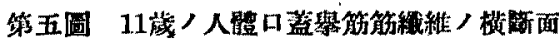
麻大 $200 \times$

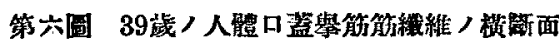
原大 $200 x$

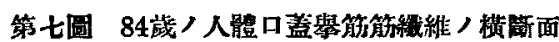
陑大 $200 x$

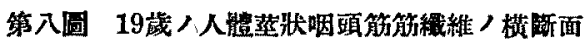
原大 $200 x$

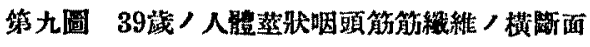
麻大 $200 x$

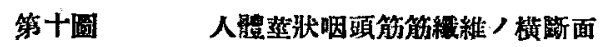
限大 $200 x$

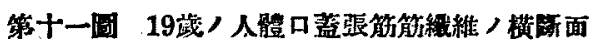

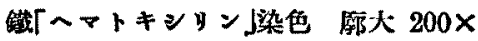

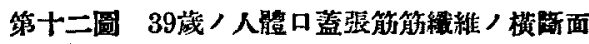
较「ヘマトキシタン染色 初大 $200 x$

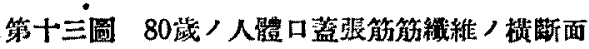
鐵「ヘマトキシタン染色 涯太 $200 \times$

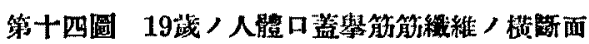
鐵「ヘアトキシタン染色 啊大 $200 \times$

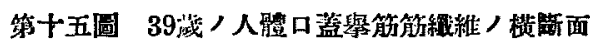

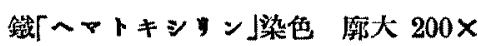

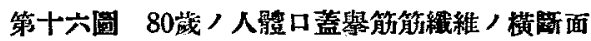

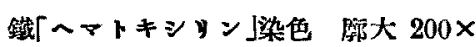

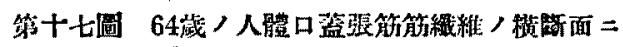
於ケル彈力織維

「レッ゙ルチン・フクシン」染色 䣝人 $150 \times$

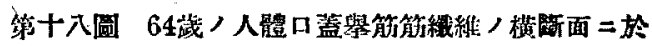
クル彈力鼣䊒

「レソルチン・フッシン染色 厥大 $150 \times$

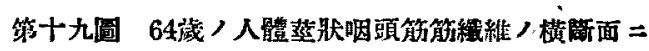
於多彈力繳䊒

「レソルキン・フクシン染色 麻火 $150 \times$ 


\section{Über den histologischen Bau von Tubenmuskeln des Menschen.}

\section{Von}

\section{Dr. Kaname Okada.}

In der I. Abteilung studierte der Verf. den histologischen Bau von Tubenmuskeln des Menschen, besonders $M$. Tensor veli palatini und M. Levator veli palatini, welche wahrscheinlich bei der Oeffnung und Schliessung der Tuba Eustachii eine wichtige Rolle spielen.

Das ihm zur Verfuegung gestandene Material stammte von I5 Leichen im Alter von II jahren bis 84 jahren. Beide Muskeln wurden in 10\%iger Formalinloesung fixiert und dann nach der Methylalkohol-Celloidin-Methode von Seki eingebettet. Die Celloidinschnitte wurden nach der Heidenheinschen Eisenhaematoxylinmethode nach der Azanfaerbung und der Weigertschen Faerbung mit Haematoxylin-eosin gefaerbt. Die Flaechenmessung an den Querschnitten der beiden Muskeln wurde mit Hilfe eines Planimeters ausgeführt.

Die Resultate der Untersuchung sind folgende:

I) Die Faserdicke der beiden Muskeln erreicht im mittleren Alter das Maximum und nimmt dann mit fortschreitendem Alter staendig ab. Die Dickenabnahme ist beim M. Levator veli palatini kleiner als beim M. Tensor veli palatini.

2) Die Zahl der beiden Muskelfasern verkleinert sich mit fortschreitendem Alter.

3) Die Form des Querschnitts der Muskelfaser ist in der Pubertaet polygonal und im mittleren Alter mehr rundlich.

4) Waehrend das Bindegewebe zwischen den Muskelfasern beim M. Tensor veli palatini immer schwach entwickelt ist, tritt es zwischen den Muskelfasern beim $M$. Levator veli palatini stark zutage.

In der II. Abteilung hat der Verf. ferner bei dem M. styloglossus und dem M. stylopharyngeus, gerade wie bei den Tubenmuskeln, histologische Untersuchungen ausgeführt. Dabei konnte er aber, anders als bei den Tubenmuskeln, keine Altersveränderungen feststellen.

Die oben erwaehnte Rueckbildung der (Tuben) Muskeln im hohen Alter ist wahrscheinlich eine wesentliche Ursache für die Tubenstenose beim Greisen.

(Autonferat.) 